\title{
Probiotic Lactococcus lactis: A Review
}

\author{
Priti Khemariya $^{1^{*}}$, Sudhir Singh ${ }^{1}$, Gopal Nath ${ }^{2}$, Anil K Gulati ${ }^{2}$ \\ ${ }^{I}$ Post-Harvest Technology Lab, Indian Institute of Vegetable Research, P.O. Jakkhini, Shahanshahpur, Varanasi (Uttar Pradesh)-221305, India \\ ${ }^{2}$ Department of Microbiology, Institute of Medical Sciences, Banaras Hindu University, Varanasi (Uttar Pradesh)-221005, India
}

\begin{tabular}{l}
\hline A R T I C L E I N F O \\
Review Article \\
Received 24 February 2016 \\
Accepted 07 March 2017 \\
\hline
\end{tabular}

Keywords:

Lactococcus lactis

Probiotic

Bacteriocinogenic

Therapeutic role

*Corresponding Author:

E-mail: preeti_904@yahoo.com \begin{abstract}
A B S T R A C T
Lactococcus lactis plays a critical role in food, dairy and health sectors. In food and dairy industries, it is found in production processes of various fermented products such as sausages, pickled vegetables, beverages such as beer and wine, breads, soymilk kefir, sour milk, butter, cream, fresh cheese and different types of cheeses, like Cheddar, Colby, Cottage cheese, Camembert, cream cheese, Roquefort and Brie. Additionally, there is an increasing interest towards the possible health benefits of the probiotic activity of this organism which generally is species and strain specific and depends upon the survival in gastrointestinal tract with sufficient number. Certain strains have the ability to produce antimicrobial peptide called nisin which exhibits preservative potential. Therefore, application of bacteriocinogenic Lactococcus lactis in food and dairy sectors to preserve foods as a natural way and contributing health promoting attributes due to probiotic activity would definitely fulfil today's consumer demands. This paper aimed to review the adaptation, antibiotic resistance, therapeutic and preservation potential of bacteriocinogenic and probiotic Lactococcus lactis.
\end{abstract}

DOI: https://doi.org/10.24925/turjaf.v5i6.556-562.690

\section{Introduction}

Lactococcus (L.) lactis is an important organisms of lactic acid bacteria which secrete lactic acid as one of the main fermentation products of carbohydrate metabolism contributing to the extension of the shelf life and reduction of lactose content (Roissart, 1994). Besides, an antagonistic extracellular peptide namely nisin is also produced that exhibits broad antibacterial activity against Gram positive spoilage and pathogenic bacteria (Chung et al., 1989; Klaenhammer 1993). This Gram-positive, catalase negative, non-motile, non-sporing, heterofermentative and coccus bacterium has been an important model organism for many years due to its extra-ordinary industrial importance as primary components of dairy starter cultures and critical role in public health maintenance. Four sub-species of L. lactis have been recognized so far i.e. L. lactis ssp. cremoris, L. lactis ssp. hordniae, L. lactis ssp. lactis (including biovar diacetylactis) and L. lactis ssp. tructae. Amongst, L. lactis ssp. lactis, L. lactis ssp. cremoris, L. lactis ssp. lactis biovar diacetylactis (Schleifer et al., 1985; Stiles and Holzapfel, 1997) exhibit tremendous application in food and dairy industries as starter cultures and probiotics as well. Probiotics can be defined as live microorganisms which provide health benefits to the host when administered in adequate amounts (FAO/WHO, 2002). Probiotic beneficial effect for the host are suppression of the colonization of pathogens, reduction of gastrointestinal infections, control of serum cholesterol, immune stimulation, improvement in lactose digestion, increase in bio-availability of minerals, vitamins synthesis and anti-carcinogenic activity (FAO/WHO, 2002; Chan and Zhang, 2005; Galdeano et al., 2007; Oelschlaeger, 2010).

\section{Niche-Specific Adaptation}

L. lactis is widely distributed in a variety of niches such as dairy products, fermented meats, fermented vegetables, minimally processed fruits and vegetables such as mung bean sprouts or corn, sourdough, silage, beverages, sewage, grasses and also in the genital, intestinal and respiratory tracts of human beings and animals. Its presence in human beings or animals is accidental because they are not normally found in significant numbers in excrement or soil. It is believed that from non-dairy environments, due to their efficient uptake and fermentation of lactose via PEP-PTS, lactococci have been well adapted to grow in milk and now the most recognized habitat are untreated milk, fermented milk, cheeses, sour milk and other dairy products (Axelsson, 1998). Bachmann et al. (2012) has performed the transition of a plant isolate of L. lactis to the dairy environment by propagating three independent cultures for 1000 generations in milk. They have reported 
that the adapted strains exhibited significantly better growth in milk and showed several common characteristics with a dairy strain. Their findings were in agreement with a naturally occurring evolutionary process.

L. lactis has very flexible genome to get adapted in various niches. Due to this diverse niche specific adaptation L. lactis possesses a high level of diversity as for as their functional, structural and metabolic traits are concerned. Fermenting plant material consists of a highly variable niches in terms of chemical composition. These have a wide availability of carbohydrates instead of lactose as growth substrates. Moreover, protein concentrations are much lower than the dairy environment. As a result, strains isolated from fermenting plant material do not harvest amino acids through proteolysis. Instead, these depend on amino acid biosynthesis and therefore exhibit fewer amino acid auxotrophies. However, dairy isolates have high number of amino acid auxotrophies that allow these to utilize milk proteins as a source of amino acids (Siezen et al., 2005; Makarova et al., 2006.). Moreover, L. lactis of fermenting plant materials revealed several genes for the degradation of complex plant polymers like xylan, arabinan, glucans, and fructans and for the uptake and conversion of plant cell wall degradation products like arabinose, xylose, galacturonate, glucuronate, and gluconate which are absent in dairy isolates (Siezen et al., 2008). Hence, it can be concluded that strains adapted to the plant environment will exhibit large metabolic diversity than dairy strains.

Lactococci of plant environment generally live in synergy with various bacteria and fungi as biofilms, which could have similar and complementary enzymes (e.g., pectinases), allowing lactococci to grow on the plant cell wall breakdown products produced by other microbes. Besides, lactococci also possesses genes for plant niche adaptations such as genes of nisin biosynthesis and immunity for defense and stress response. The latter involves several extra putative transport systems for uptake of iron, potassium, and polyamines. Recently, it has been shown that some non-dairy L. lactis strains produce glutamate dehydrogenase, which converts glutamate to $\alpha$-ketoglutarate, the first step in the production of flavor compounds from amino acid (Tanous et al., 2002). Therefore, strains isolated from non-dairy environments are gaining interest to be used for different flavor activities in various dairy fermented products.

Several studies have reported the biodiversity of $L$. lactis with the help of several molecular approaches. An extensive genotypic and phenotypic diversity analysis of a large set of strains from dairy and non-dairy origins confirmed the existence of two major genomic lineages cremoris and lactis (Rademaker et al., 2007). However Khemariya et al. (2012) reported single genomic lineage lactis in isolates of dairy and non-dairy samples by Multilocus Sequence Analysis (MLSA). Seizen et al. (2011) performed whole-genome diversity analysis on $L$. lactis strains of dairy and plant origins. Comparative genome hybridization analysis with multi strain microarrays was applied in these strains to assess presence or absence of genes and gene clusters. Their study supports that L. lactis is genome wise very flexible species and their diversification is related to niche adaptation. Their data support that the ancestor of $L$. lactis originally inhabited the plant environment, but was quiet capable to colonize other habitats successfully due to its genomic flexibility (Quiberoni et al., 2001).

\section{Therapeutic Roles}

Recently L. lactis has been entered the biomedical area. This is the most important development as the result of molecular genetics investigation. Nowadays, it is becoming the fast evolving area of interest. L. lactis is the first alive organism to be utilized as a genetically modified organism for treating various diseases. As this bacterium is easy to handle, non-commensal, nonpathogenic and non-invasive therefore has been used as in vivo delivery vector for various antigens and immunomodulatory proteins as well. Nowadays, L. lactis is also becoming the most suitable expression cell factory for various heterologous protein secretion (Le Loir et al., 2005) such as reporter molecule, bacterial, eukaryotic, viral antigens, interleukins, allergens, virulence factors, bacteriocins and enzymes. The insertion of antigen to the immune system as particulate lactococcal form inhibits the development of host immune-tolerance that generally induced by oral administration of soluble antigens (Wold et al., 1989). Moreover, L. lactis elicits only a weak immune response against itself (Robinson et al., 1997; Wells and Mercenier, 2008).

Several recent studies have reported excellent response with in vitro or animal models. It has been proved that $L$. lactis containing interleukin can treat and prevent IBD (Inflammatory Bowel Disease) (Bahey-ElDin and Grahan, 2010). High potential of E7 antigen and interleukin-12 secreting lactococci strains as mucosal vaccine have been observed advantageous in future for prophylactic and therapeutic uses by inducing systemic and mucosal immune responses in mice against human papilloma-virus type 16-induced tumors (BermúdezHumarán et al., 2008). It has been reported to be used as a vaccine delivery system against Helicobacter $(H$.) pylori infection in mice by expressing $H$. pylori urease subunit B gene in L. lactis (Lee et al., 2001). It has been made live vaccine against brucellosis by targeting and producing Brucella abortus antigen L7/L12 in L. lactis (Ribeiro et al., 2002). It doesn't colonize the bowel and colon and doesn't exhibit any side effects or immune-tolerance as well if used for a long period (Nouaille et al., 2003). Maruo et al. (2011) demonstrated the protective role of orally administered milk fermented with a Lactococcus strain in mice infected with IFV (Influenza virus). Milk fermented with L. lactis ssp. cremoris FC has improved survival rates and reduction in body weight and pulmonary viral titer after IFV infection in mice.

Besides providing natural benefits like providing lactase in gut of lactose-intolerant consumers it has been also proved beneficial in delivering digestive enzymes to pancreatic deficient humans. Moreover, being non- 
pathogenic food grade bacteria L. lactis shows much efficacy as live antigen and enzyme carriers, thus it is beneficial for the oral administration than the attenuated pathogens. Oral vaccination of mice has also been reported against rodent malaria using recombinant $L$. lactis expressing MSP-119 (D'Souza et al., 2012). In this way, the GRAS (Generally Regarded as Safe) status of $L$. lactis is a clear advantage for its use in biomedical area.

\section{Antibiotic Resistance}

L. lactis acts as a reservoir of antimicrobial-resistance genes/antibiotic resistance genes and/or virulence genes which are found on mobile genetic elements like plasmids or transposons. These antibiotic resistance genes can effectively be transferred to other pathogens either by food chain or in the gastrointestinal tract of human and animals which reside in the host's body and cause infections to host and thus producing multidrug resistant strains (Teuber 1999; Salyers et al., 2004). Under these circumstances it is difficult to eliminate infection from host body caused by multi drug resistant pathogens. Therefore, food grade L. lactis must be characterized to ensure the absence of acquired antimicrobial resistance to be probiotic potential and could be used in different formulations for human and animal consumption (Belen Florez et al., 2005; Liasi et al., 2009).

Khemariya et al. (2013a) has performed antibiotic susceptibility for a set of $L$. lactis strains and reported that all isolates were susceptible to ampicillin ( $\beta$-lactam antibiotic), spectinomycin of aminoglycosides, erythromycin and spiramycin of macrolide group, ciprofloxacin, and rifampicin of quinolones and trimethoprim (sulphonamides). Moreover, the isolates were resistant to fosfomycin and cefepime ( $\beta$-lactam group), nalidixic acid, pipemidic acid, and norfloxacin (quinolones), amikacin, kanamycin, and neomycin (aminoglycosides), sulphadiazine (sulphonamides), colistin, and polymixin (polypeptide), teicoplanin (glycopeptides), and nystatin and amphotericin B of the antifungal group of antibiotics. Liasi et al., (2009) also reported the resistance of $L$. lactis to aminoglycosides, sulphonamides, $\beta$-lactam, polypeptide and quinolone groups of antibiotics. Termmerman et al. (2003), Zhou et al. (2005) and Liasi et al. (2009) also showed the resistance towards Gram-negative spectrum antibiotics (nalidixic acid, pipemidic acid and norfloxacin) and aminoglycoside antibiotics (amikacin, kanamycin, and neomycin).

The interaction between antibiotics and probiotic bacteria in the gastrointestinal tract (GIT) depends upon their amount of active compounds (Todorov et al., 2011). Thus, if a particular antibiotic is inhibitory to probiotic $L$. lactis, the viability of probiotic bacteria would be affected in GIT, hence, determination of minimal inhibitory concentration (MIC) values plays an important role for proper evaluation of these interactions. But due to their long-term application, antibiotics may accumulate in the GIT and MIC be reached which affects the viability of probiotic bacteria.

\section{Bio-Preservation Of Food}

The increasing concern of consumers' towards the possible adverse health effects due to the chemical additives in food has led the food industry to search effective natural food preservative with no harm to host and the environment. Bacteriocins offer potential applications in food preservation and its use in food industries can help in reducing the usage of chemical preservatives and harsh heat treatments to get naturally preserved foods with rich organoleptic and nutritional properties. Nisin is extensively characterized bacteriocin produced by certain strains of L. lactis ssp. lactis which is used as biopreservative in the preservation of processed cheese, milk, dairy desserts, mayonnaise, bacon, meat products, fish, alcoholic beverages and canned foods (Ross et al., 2002; Suganthi et al., 2012). Nisin have found a widespread application in food industry and commercially available as food additive E234 and Nisaplin TM (Delves-Broughton et al., 1996). It is permitted as a food additive in at least 46 countries and has been granted GRAS status by Food and Drug Administration (FDA).

Nisin is the only bacteriocin licensed as a good food grade preservative. It inhibits the growth of Gram-positive spoilage bacteria such as Listeria, Staphylococcus and Mycobacterium, and spore-forming bacteria Bacillus and Clostridium. The spores of these bacteria are more sensitive to nisin than their vegetative cells, so nisin is often applied in heat-processed food such as canned vegetables. The preservative property of L. lactis is also attributed due to its antimicrobial metabolites includes ethanol, hydrogen peroxide, diacetyl and organic acids such as lactic, acetic and propionic acid. Not only these antimicrobials prevent spoilage by inhibiting pathogenic microorganisms but also enhance distinctive taste, flavor, aroma, appearance, color and texture. The organic acids create an acidic environment leading to the reduction of intracellular $\mathrm{pH}$ and dissipation of membrane potential, unfavorable for the growth of many pathogenic and spoilage microorganisms. The organic acid causes dissociated molecules across the cell membrane and interferes the normal functioning of metabolic reactions (Suskovic et al., 2010). Acids are generally exhibited their antimicrobial action against both gram-positive and gram-negative bacteria as well as yeast and molds by interfering cell membrane potentiality, inhibiting active transportation and metabolic functions and reducing intracellular pH (Ross et al., 2002). Being strong oxidizing, hydrogen peroxide exerts antimicrobial activity on bacterial cell and causes destruction of basic molecular structures of cell proteins (Lindgren and Dobrogosz, 1990). Thus, each antimicrobial metabolite exerts their antagonistic effect by the collective action and provides hurdle to spoilage microorganisms to grow and proliferate in food products.

\section{Enumeration of L. lactis}

Isolation, identification and characterization of any microbial population could be performed either by culture 
dependent and culture independent manner. Culture dependent approach includes the cultivation of microorganisms from environmental samples on various laboratory media. Enormous efforts have been made for the isolation and identification of $L$. lactis based on culture dependent approaches. The growth of L. lactis is characterized by numerous complex nutritional requirements containing complex nitrogen sources (peptides), carbon sources, vitamins and minerals to supply of trace elements at optimal concentrations. These factors complicate the formulation of a suitable growth media. Several medium formulations have been proposed in the past for the enumeration of lactococci. The complex media MRS (de Man et al., 1960) and M17 (Terzaghi and Sandine, 1975) have been reported as suitable media for growth of L. lactis. Tornadijo et al. (1995) compared various media, such as M17, Rogosa agar, MSE (Mayeux-Sandine-Elliker) and KAA for isolation of lactic acid bacteria from raw milk and reported that M17 and MSE were the most suitable media for lactococcal growth. Another growth media such as NRCLA (Neutral red chalk lactose agar) (Harrigan and McCance, 1966) CM (De Vuyst and Vandamme, 1992), SM8 (De Vuyst, 1995) and M17S (Li et al., 2000) are also used for the cultivation of L. lactis. Presently, many investigators use a defined growth medium described by Otto et al., (1983) and modified by Poolman and Konings (1988) which supports the growth of L. lactis at reasonably high specific growth rates. This medium contains virtually all building blocks for biosynthesis of macromolecules which complicates the study of metabolic pathways. A minimal growth medium has also been developed containing glucose, acetate, vitamins and eight amino acids for growth of L. lactis ssp. lactis (Jenson and Hammer, 1993).

Proteolytic and non-proteolytic strains have been separated on FSDA agar (Fast Slow Differential Agar) and PCA (Plate Count Agar) supplemented with $1 \%$ milk (Huggins and Sandine, 1984). The reducing power of lactococci and organic acid production have been also tested on Turner agar and modified KCA (Turner et al., 1963; Waes, 1968). Application of acid indicators and selective antibiotics has also been reported for the isolation of L. lactis from different environmental sources. A non-specific medium, plate count agar enriched with milk was used to isolate wild-type lactococci from complex microflora. This medium was made specific for lactococci by adding two antibiotics, nalidixic acid to inhibit gram-negative bacteria and natamycin against the growth of yeasts and molds (Desmasures and Gueguen, 1997). Isolation of lactococci from raw milk samples has successfully been carried out by the application of bromo cresol purple $(20 \mathrm{mg} / \mathrm{l})$, nalidixic acid $(40 \mathrm{mg} / \mathrm{l})$ and natamycin $(10 \mathrm{mg} / \mathrm{l})$ to the plate count agar containing sterilized skimmed milk (Corroler et al., 1998). Inhibitors of gram negative bacteria (i.e. sodium azide) and acidity indicator (i.e. bromocresol purple) have been tested to PCA or M17 agar to improve for lactococcal recovery (Desmasures and Gueguen, 1997). Gemelas et al. (2013) has reported KCA the most selective medium for specific enumeration of lactococci.

Savoie et al. (2007) studied the effects of medium composition and fermentation parameters on the properties of L. lactis ssp. lactis and L. lactis ssp. cremoris and reported that the growth of L. lactis favored under $\mathrm{pH}$ control in whey-based media. The effect of $\mathrm{KH}_{2} \mathrm{PO}_{4}$ on the chemical environment and on the growth of L. lactis in co-culture was investigated in a liquid and in a gelled microbiological medium at $12^{\circ} \mathrm{C}$ and an initial $\mathrm{pH}$ of 6.2. At all gelatin concentrations studied, addition of $\mathrm{KH}_{2} \mathrm{PO}_{4}$ increased the growth rate and the stationary cell concentration of $L$. lactis. The effect of citrate on growth at a very acidic $\mathrm{pH}$ value was studied with a natural cheese strain L. lactis ssp. lactis biovar diacetylactis CRL264. Maximum specific growth rate and specific glucose consumption rate were stimulated by citrate in the medium. Moreover, a more efficient energy metabolism has been reported by correlation of biomass yields relative to glucose consumption (Sanchez et al., 2008).

Culture independent approaches are molecular methods based on isolation of total microbial DNA or RNA without any cultivating steps which provide an excellent tool for detection, identification and characterization of microorganisms of environmental samples, foods and other complex ecosystems. During the last decades, lots of approaches have been introduced under culture independent molecular methods which are frequently used in the identification and characterization purposes of L. lactis such as Culture-Independent Polymerase Chain Reaction (Salbi et al., 2014;) 16S rDNA Sequencing (Aquilanti et al., 2007; Khemariya et al., 2013b), PCR-Denaturing Gradient Gel Electrophoresis (PDGE) (Mrkonjić Fuka et al., 2010; Pogačić et al., 2010; Marui et al., 2015;), PCR-Temporal Temperature Gradient Electrophoresis (TTGE) (ElBaradei et al., 2008), Single-Strand Conformation Polymorphism-PCR (SSCP-PCR) (Saubusse et al., 2007), Real Time PCR (qPCR) (Grattepanche et al., 2005; Ruggirello et al., 2014), Fluorescence in situ Hybridization (FISH) (Miks-Krajnik and Babuchowski, 2014), Amplified Ribosomal DNA Restriction Analysis (Partial ARDRA) (Delgado and Mayo, 2003), Length Heterogeneity PCR (LH-PCR) (Brusetti et al., 2006), Multilocus Sequence Analysis (MLSA) (Rademarker et al., 2007; Khemariya et al., 2012) (GTG) $)_{5}$-PCR Fingerprinting (Rademarker et al., 2007; Khemariya et al., 2014), PCR-Restriction Fragment Length Polymorphism (PCR-RFLP) (Deveau et al., 2003; Khemariya et al., 2013b), Multiple Locus Minisatelite Typing (MLVA) (Que'ne'e et al., 2005), RAPD-PCR (Randomly Amplified Polymorphic DNA-PCR) (Samaržija et al., 2002), Pulse Field Gel Electrophoresis (PFGE) (Campo et al., 2002), Repetitive Element Sequence based PCR (RepPCR) (Fernandez et al., 2010), Comparative Genomic Hybridization (CGH) (Taibi et al., 2010), Nested PCR (Khemariya et al., 2013c), Multiplex PCR (Pu et al., 2002) and Sau-PCR (Corich et al., 2005). 


\section{Conclusion}

Natural food fermentations usually depend upon the microbial populations of raw materials and are thus subjected to variations in flavor and quality. These natural food fermenting microbes cause food related diseases. They also cause spoilage in production and storage of food and beverages. Antibiotics and food preservatives are generally used to combat these microbes. However, potential danger of antibiotic resistant bacteria and demand of purer and safer foods by consumers, there is urgent interest to replace harmful substances by easily degradable and harmless natural products. However, development of a new generation of antimicrobial agents is a difficult task. In this respect, bacteriocinogenic and probiotic L. lactis is the convenient strategy to control food fermentations and to establish on the raw materials as the dominant population during early stage of fermentation. Moreover, application of nisin producing $L$. lactis strains as starter cultures or protective cultures' for in situ control of food pathogens is also one of the possible ways to improve food safety by controlling undesirable microflora in foods. In this context both traditional cell culture methods, as well as the nucleic acid-based enumeration methods offer advantages and limitations for enumerating probiotic and bacteriocinogenic $L$. lactis. The specific health promoting activities of L. lactis have been subjected to thorough in vitro studies and several of its therapeutic roles are still under clinical human trials. Probiotics can be dangerous, as these have been linked to an increase in mortality rate if administered to severely immuno-compromised persons, hence subsequent studies are essentially required to evaluate health-promoting activity of probiotic L. lactis in human body.

\section{References}

Aquilanti L, Silvestri G, Zannini E, Osimani A, Santarelli S, Clementi F. 2007. Phenotypic, genotypic and technological characterization of predominant lactic acid bacteria in Pecorino cheese from central Italy. J Appl Microbiol., 103:948-960.

Axelsson L. 1998. Lactic Acid Bacteria: Classification and Physiology. In: Lactic Acid Bacteria, Ed. Salminen S, von Wright A, Marcel Dekker, INC., New York, second edition 173.

Bachmann H, Starrenburg MJC, Douwe Molenaar, Michiel Kleerebezem, van Hylckama Vlieg JET. 2012. Microbial domestication signatures of $L$. lactis can be reproduced by experimental evolution. Cold Spring Harbor Laboratory Press; ISSN 1088-9051/12; 22:115-124.

Bahey-El-Din M, Gahan CG. 2010. Lactococcus lactis: from the dairy industry to antigen and therapeutic protein delivery. Discov Med., 9(48):455-61.

Belen Florez A, Delgado S, Mayo B. 2005. Antimicrobial susceptibility of lactic acid bacteria isolated from a cheese environment. Can J Microbiol., 51:51-58.

Bermudez-Humaran LG, Cortes-Perez NG, Ah-Leung S, Lefevre F, Yang G, Pang Q, Wu C, Zeng Y, Adel-Patient K, Langella P. 2008. Current prophylactic and therapeutic uses of a recombinant Lactococcus lactis strain secreting biologically active interleukin-12. J Mol Microbiol Biotechnol., 14(1-3):809.
Brusetti L, Borin S, Mora D, Rizzi A, Raddadi N, Sorlini C, Daffonchio D. 2006. Usefulness of length heterogeneity-PCR for monitoring lactic acid bacteria succession during maize ensiling. FEMS Microbiol Ecol., 56(1):154-64.

Campo N, Dias M, Daveran-Mingot ML, Ritzenthalter P, Le Bourgeois P. 2002. Genome plasticity in Lactococcus lactis. Antonie van Leeuwenhoek., 82:123-244.

Chan ES, Zhang Z. 2005. Bioencapsulation by compression coating of probiotic bacteria for their protection in an acidic medium. Process Biochem., 40:3346-3351.

Chung KT, Dickson JS, Crouse JD. 1989. Effect of nisin on growth of bacteria attached to meat. Appl Environ Microbiol., 55:13291333.

Corich V, Mattiazzi A, Soldati E, Carraro A, Giaocomini A. 2005. Sau-PCR, a novel amplification technique for genetic fingerprinting of microorganisms, Appl Environ Microbiol., 71:6401-6406.

Corroler D, Mangin I, Desmasures N, Gueguen M. 1998. An ecological study of Lactococci isolated from raw milk in the Camembert cheese registered designation of origin area. Appl Environ Microbiol., 64:4729-4735.

D’Souza R, Pandeya DR, Hong ST. 2012. Review: Lactococcus lactis: An efficient Gram positive cell factory for the production and secretion of recombinant protein. Biomed Res, 23 (1):1-7.

De Man JC, Rogosa M, Sharpe ME. 1960. A medium for the cultivation of lactobacilli. J Appl Bacteriol., 23:130-135.

De Vuyst L. 1995. Nutritional factors affecting nisin production by Lactococcus lactis ssp. lactis NIZO 22186 in a synthetic medium. J Appl Bacteriol., 78:28-33.

De Vuyst L, Vandamme EJ. 1992. Influence of the carbon source on nisin production in Lactococcus lactis ssp. lactis batch fermentations. J Gen Microbiol., 138:571-578.

Delgado S, Mayo B. 2003. Phenotypic and genetic diversity of Lactococcus lactis and Enterococcus spp. strains isolated from Northern Spain starter-free farmhouse cheeses, Int $\mathrm{J} F d$ Microbiol., 90:309-319.

Delves-Broughton J, Blackburn P, Evans RJ, Hugenholtz J. 1996. Applications of the bacteriocin, nisin. Antonie van Leeuwenhoek., 69:193-202.

Desmasures N, Gueguen M. 1997. Monitoring the microbiology of high quality milk by monthly sampling over 2 years. J Dairy Res., 64(2):271-280.

Deveau H, Moineau S. 2003. Use of RFLP to characterize Lactococcus lactis strains producing exopolysaccharides. J Dairy Sci., 86:1472-1475.

EI-Baradei A, Delacroix-Buchet JC, Ogier. 2008. Bacterial biodiversity of traditional Zabady fermented milk. Int $\mathrm{J} \mathrm{Fd}$ Microbiol., 121:295-301.

FAO/WHO. 2002. Guidelines for the evaluation of probiotics in food, report of a joint FAO/WHO working group on drafting guidelines for the evaluation of probiotics in food. London, ON, Canada.

Fernandez E, Alegria A, Delgado S, Mayo B. 2010. Phenotypic, genetic and technological characterization of Lactococcus garvieae strains isolated from a raw milk cheese. Int Dairy J., 20:142-148.

Galdeano C, de Moreno A, Vinderola G, Bibas Bonet ME, Perdigon G. 2007. A proposal model: mechanisms of immunomodulation induced by probiotic bacteria. Review. Clin Vacc Immunol., 14:485-492.

Gemelas L, Rigobello V, Ly-Chatain MH, Demarigny Y. 2013. Selective Lactococcus enumeration in raw milk. Fd Nutri Sci., 4:49-58.

Grattepanche F, Lacroix C, Audet P, Lapointe G. 2005. Quantification by real-time PCR of Lactococcus lactis ssp. cremoris in milk fermented by a mixed culture. Appl Microbiol Biotechnol., 66:414-421.

Harrigan FW, McCance EM. 1966. Laboratory methods in microbiology. Academic Press, London, New York: 285. 
Huggins AM, Sandine WE. 1984. Differentiation of fast and slow milk coagulating isolates in strains of Streptococci. J Dairy Sci., 67(8):1674-1679.

Jenson PR, Hammer K. 1993. Minimal requirements for exponential growth of Lactococcus lactis. Appl Environ Microbiol., 59:4363-4366.

Khemariya P, Singh S, Nath G, Gulati AK. 2014. Diversity analysis, batch fermentation and characterization of nisin in identified strains of L. lactis spp. lactis. Fd Biotechnol., 28 (2):142-161.

Khemariya P, Singh S, Nath G, Gulati AK. 2013a. Isolation, identification, and antibiotic susceptibility of nis+ L. lactis from dairy and non-dairy sources. Czech J Fd Sci., 31(4):323-331.

Khemariya P, Singh S, Nath G, Gulati AK. 2013b. Development of a PCR-RFLP assay for the identification of L. lactis ssp. lactis and cremoris. Ann Microbiol., 63(1):109-115.

Khemariya P, Singh S, Nath G, Gulati AK. 2013c. Subspeciesspecific nested PCR assay for detection of L. lactis spp. lactis and L. lactis spp. cremoris. Fd Biotechnol., 27(3):222-234.

Khemariya P, Singh S, Nath G, Gulati AK. 2012. Diversity analysis of dairy and non-dairy strains of L. lactis ssp. lactis by multilocus sequence analysis (MLSA). Ann Microbiol., 63 (3):1065-1074.

Klaenhammer TR. 1993. Genetics of bacteriocins produced by lactic acid bacteria. FEMS Microbiol Rev., 12:39-86.

Le Loir Y, Azevedo V, Oliveira SC, Freitas DA, Miyoshi A, Bermudez-Humaran LG, Nouaille S, Ribeiro LA, Leclercq S, Gabriel JE, Guimaraes VD, Oliveira MN, Charlier C, Gautier M, Langella P. 2005. Protein secretion in Lactococcus lactis: an efficient way to increase the overall heterologous protein production. Microb Cell Fact., 4:2-13.

Lee MH, Roussel Y, Wilks M, Tabaqchali S. 2001. Expression of Helicobacter pylori urease subunit B gene in Lactococcus lactis MG1363 and its use as a vaccine delivery system against $H$. pylori infection in mice. Vaccine., 19(28-29):3927-35.

Li C, Ouyang F, Bai J. 2000. Extractive cultivation of Lactococcus lactis using a polyethylene glycol/ $\mathrm{MgSO}_{4} \cdot 7 \mathrm{H}_{2} \mathrm{O}$ aqueous two phase system to produce nisin. Biotechnol Lett., 22:843-847.

Liasi SA, Azmi TI, Hassan MD, Shuhaimi M, Rosfarizan M, Ariff AB. 2009. Antimicrobial activity and antibiotic sensitivity of three isolates of lactic acid bacteria from fermented fish product, Budu. Malay J Microbiol., 5:33-37.

Lindgren, Dobrogosz WJ. 1990. Antagonistic activities of lactic acid bacteria in food and feed fermentations, FEMS. Microbiol Rev., 87:149-164.

Makarova K, Slesarev A, Wolf Y, Sorokin A, Mirkin B, Koonin E, Pavlov A, Pavlova N, Karamychev V, Polouchine N, et al. 2006. Comparative genomics of the lactic acid bacteria. Proc Natl Acad Sci., 103:15611-15616.

Marui J, Boulom S, Panthavee W, Momma M, Kusumoto K, Nakahara K, Saito M. 2015. Culture-independent bacterial community analysis of the salty-fermented fish paste products of Thailand and Laos. Biosci Microbiota Fd Health., 34(2): 45 52.

Maruo T, Gotoh Y, Nishimura H, Ohashi S, Toda T, Takahashi K. 2011. Oral administration of milk fermented with Lactococcus lactis ssp. cremoris FC protects mice against influenza virus infection. Lett Appl Microbiol., 55:135-140.

Miks-Krajnik M, Babuchowski A. 2014. 16S rRNA-targeted oligonucleotide probes for direct detection of Propionibacterium freudenreichii in presence of Lactococcus lactis with multicolour fluorescence in situ hybridization. Lett Appl Microbiol., 59(3):320-7.

Mrkonjić Fuka M, Engel M, Skelin A, Redžepović S, Schloter M. 2010. Bacterial communities associated with the production of artisanal Istrian cheese. Int J Fd Microbiol., 142:19-24.

Nouaille S, Ribeiro LA, Miyoshi A, Pontes D, Le Loir Y, Oliveira SC, Langella P, Azevedo V. 2003. Heterologous protein production and delivery systems for Lactococcus lactis. Genet Mol Res., 2:102-111.

Oelschlaeger TA. 2010. Mechanisms of probiotic actions-A review. Int J Med Microbiol., 300:57-62.
Otto R, ten Brink B, Veldkamp H, Konings WN. 1983. The relation between growth rate and electrochemical proton gradient of Streptococcus cremoris. FEMS Microbiol Lett., 16:69-74.

Pogačić T, Samaržija D, Corich V, Maura D, Kagkli DM, Giacomini A, et al. 2010. Microbiota of Karakačanski Skakutanac, an artisanal fresh sheep cheese studied by cultureindependent PCR-ARDRA and PCR-DGGE. Dairy Sci Technol., 90:461-468.

Poolman B, Konings WN. 1988. Relation of growth of Streptococcus lactis and Streptococcus cremoris to amino acid transport. J Bacteriol., 170:700-707.

Pu ZY, Dobos M, Limsowtin GKY, Powell LB. 2002. Integrated polymerase chain reaction-based procedures for the detection and identification of species and subspecies of the Gram positive bacterial genus Lactococcus. J Appl Microbiol., 93:353-361.

Que'ne'e, P, Lepage E, Scott Kim W, Vegnagud G, Gruss A. 2005. Minisatellite polymorphism as a tool to distinguish closely related Lactococcus lactis strain. FEMS Microbiol Lett., 248:101-109.

Quiberoni A, Rezaiki L, El Karoui M, Biswas I, Tailliez P, Gruss A. 2001. Distinctive features of homologous recombination in an 'old' microorganism Lactococcus lactis. Res Microbiol., 152: 131-139.

Rademarker JLW, Herbet H, Starrenburg MJC, Naser SM, Gevers D, Kelly WJ, Hugenholtz J, Swings J, Vlirg JET. 2007. Diversity analysis of dairy and non-dairy Lactococcus lactis isolates using a novel multilocus sequence analysis scheme and (GTG)5-PCR fingerprinting. Appl Environ Microbiol., 73:71287137.

Ribeiro LA, Azevedo V, Le Loir Y, Oliveira SC, Dieye Y, Piard JC, Gruss A, Langella P. 2002. Production and targeting of the Brucella abortus antigen L7/L12 in Lactococcus lactis: a first step towards food-grade live vaccines against brucellosis. Appl Environ Microbiol., 68(2):910-916.

Robinson K, Chamberlain LM, Schofield KM, Wells JM, Le Page RW. 1997. Oral vaccination of mice against tetanus with recombinant Lactococcus lactis. Nat Biotechnol., 15(7):653-657.

Roissart H, Luquet. 1994. Lactic acid bacteria: fundamental and technological aspects. Uriage, Lorica, France 1:605. ISBN 2 950747701

Ross RP, Morgan S, Hill C. 2002. Preservation and fermentation: past, present and future. Int J Fd Microbiol., 79:3-16.

Ruggirello M, Dolci P, Cocolin L. 2014. Detection and Viability of Lactococcus lactis throughout Cheese Ripening. PLOS ONE doi: 10.1371/journal.pone.0114280

Salbi RA, Serhan M, Bassil M. 2014. Molecular verification of two potent bacteria isolated from Darfiyeh cheese: Lactococcus lactis ssp. lactis and Lactobacillus plantarum. Adv Microbiol., 4: 609-615.

Salyers AA, Gupta A, Wang Y. 2004. Human intestinal bacteria as reservoirs for antibiotic resistance genes. Trends Microbiol., 12:412-416.

Samaržija D, Sikora S, Redžepović S, Antunac N, Havranek J. 2002. Application of RAPD analysis for identification of Lactococcus lactis ssp. cremoris strains isolated from artisanal cultures. Microbiol Res., 157:13-17.

Sanchez C, Neves AR, Cavalheiro J, Santos MM, dos GarciaQuintans N, Lopez P, Santos H. 2008. Contribution of citrate metabolism to the growth of Lactococcus lactis CRL264 at low pH. Appl Environ Microbiol., 74:1136-1144.

Saubusse M, Millet L, Delbès C, Callon C, Montel MC. 2007. Application of single strand conformation polymorphism -PCR method for distinguishing cheese bacterial communities that inhibit Listeria monocytogenes. Int J Food Microbiol., 116(1):126-35.

Savoie S, Champagne CP, Chiasson S, Audet P. 2007. Media and process parameters affecting the growth, strain ratios and specific acidifying activities of a mixed lactic starter containing aroma-producing and probiotic strains. J Appl Microbiol., 103:163-174. 
Schleifer KH, Kraus J, Dvorak C, Klipper-Balz R, Collins MD, Fisher W. 1985. Transfer of Streptococcus lactis and related streptococci to the genus Lactococcus gen. nov. Sys Appl Microbiol., 6:183-195.

Siezen RJ, Bayjanov JR, Felis GE, van der Sijde MR, Starrenburg M, Molenaar D, Wels M, van Hijum SA, van Hylckama Vlieg JE. 2011. Genome-scale diversity and niche adaptation analysis of Lactococcus lactis by comparative genome hybridization using multi-strain arrays. Microb Biotechnol., 4(3):383-402.

Siezen RJ, Starrenburg MJC, Boekhorst J, Renckens B, Molenaar D, van Hylckama Vlieg JET. 2008. Genome-scale genotypephenotype matching of two Lactococcus lactis isolates from plants identifies mechanisms of adaptation to the plant niche. Appl Environ Microbiol., 74(2):424-436.

Siezen RJ, Renckens B, van Swam I, Peters S, van Kranenburg R, Kleerebezem M, de Vos WM. 2005. Complete sequences of four plasmids of Lactococcus lactis ssp. cremoris SK11 reveal extensive adaptation to the dairy environment. Appl Environ Microbiol., 71: 8371-8382.

Stiles MA, Holzapfel WH. 1997. Lactic acid bacteria of food and their current taxonomy. Int J Fd Microbiol., 36:1-29.

Suganthi V, Selvarajan E, Subathradevi C, Mohanasrinivasan V. 2012. Lantibiotic nisin: Natural preservative from Lactococcus lactis. Int res J Pharma., 3 (1):13-19.

Suskovic J, Kos B, Beganovic J, Pavunc AL, Habjanic K, Matosic S. 2010. Antimicrobial Activity- The most important property of probiotic and starter lactic acid bacteria. Fd Technol Biotechnol., 48(3):296-307.

Taïbi A, Dabour N, Lamoureux M, Roy D, La Pointe G. 2010. Evaluation of the genetic polymorphism among Lactococcus lactis ssp. cremoris strains using comparative genomic hybridization and multilocus sequence analysis. Int $\mathrm{J} \mathrm{Fd}$ Microbiol., 144:20-28.

Tanous C, Kieronczyk A, Helinck S, Chambellon E, Yvon M. 2002. Glutamate dehydrogenase activity: a major criterion for the selection of flavour-producing lactic acid bacteria strains. Antonie Leeuwenhoek., 82:271-278.
Temmerman R, Scheirlinck I, Huys G, Swings J. 2003. Culture-independent analysis of probiotic products by denaturing gradient gel electrophoresis. Appl Environ Microbiol., 69:220226.

Terzaghi BE, Sandine WE. 1975. Improved medium for lactic streptococci and their bacteriophages. J Appl Microbiol., 29:807-813.

Teuber M. 1999. Spread of antibiotic resistance with food-borne pathogens. Cell Mol Life Sci., 56:755-763.

Todorov SD, Furtado DN, Saad SMI, Tome E, Franco BDGM. 2011. Potential beneficial properties of bacteriocin-producing lactic acid bacteria isolated from smoked salmon. J Appl Microbiol., 110(4):971-986.

Tornadijo ME, Fresno JM, Bernardo A, Martin Sarmiento R, Carballo J. 1995. Microbiological changes throughout the manufacturing and ripening of a Spanish goat's raw milk cheese (Armada variety). Lait, 75:551-570.

Turner WE, Sandine PR, Elliker, Day EA. 1963.Use of tetrazolium dyes in an agar medium for differentiation of Streptococcus lactis and S. cremoris. J Dairy Sci., 46(5):380-385.

Waes. 1968. The enumeration of Aroma bacteria in BD starters. Neth Milk Dairy J., 22:29-39.

Wells JM, Mercenier A. 2008. Mucosal delivery of therapeutic and prophylactic molecules using lactic acid bacteria. Nat Rev Microbiol, 6(5):349-362.

Wold AE, Dahlgren UI, Hanson LA, Mattsby-Baltzer I, Midvetdt T. 1989. Difference between bacterial and food antigens in mucosal immunogenicity. Infect Immun., 57(9):2666-2673.

Zhou JS, Pillidge CJ, Gopal PK, Gill HS. 2005. Antibiotic susceptibility profiles of new probiotic Lactobacillus and Bifidobacterium strains. Int J Fd Microbiol., 98:211-217. 